\title{
Interactive comment on "Seasonal variation of the main tidal constituents in the Bohai Bay" by Daosheng Wang et al.
}

Anonymous Referee \#2

Received and published: 9 July 2019

please see supplement.

Please also note the supplement to this comment:

https://www.ocean-sci-discuss.net/os-2019-43/os-2019-43-RC2-supplement.pdf

Interactive comment on Ocean Sci. Discuss., https://doi.org/10.5194/os-2019-43, 2019. 